\title{
Kimura disease
}

\author{
*Abhijit Anil Patil ${ }^{1}$, P S Chandrasekar ${ }^{1}$
}

Sri Lanka Journal of Child Health, 2018; 47: 177-178

DOI: http://dx.doi.org/10.4038/sljch.v47i2.8489

(Keywords: Kimura disease, eosinophilia)

\section{Case report}

A 14 year old adolescent boy presented with left parotid and left post-aural lumps of 1 year duration, associated with pain. His growth was normal and there was no fever. Abdominal examination did not show enlargement of the liver or spleen. His white cell count and peripheral blood film showed marked eosinophilia (35\%). Roentgenograms of the chest and bones did not show any abnormalities. Skin tuberculin test was negative. Urinalysis was normal. Serum Ig E was 780 $\mathrm{IU} / \mathrm{ml}$ (normal $<200 \mathrm{IU} / \mathrm{ml}$ ). Magnetic resonance imaging of neck soft tissue showed left parotitis and left cervical lymphadenopathy. The parotid and postaural lumps were excised and sent for histopathology. Histopathology showed lobules of serous glands with many interspersed hyperplastic lymphoid follicles with prominent germinal centres and cuff of mantle zone, numerous eosinophils in stroma, infiltrating the lymphoid follicles and serous glands with focal clustering forming micro-abscesses and many thin walled vascular spaces with flattened endothelial cells, consistent with Kimura disease (Figures 1 and 2).

Left near total parotidectomy and left modified radical neck dissection were done. On follow up, child developed post-aural swellings bilaterally. As his disease is progressing we have planned to give him intravenous immunoglobulin. We are doing his urine analysis on follow up visits as Kimura disease patients are prone to develop nephrotic syndrome.

\section{${ }^{1}$ Kovai Medical Centre and Hospital, India \\ *Correspondence: abhi_neurology@rediffmail.com}

(Received on 13 November 2016: Accepted after revision on 23 December 2016)

The authors declare that there are no conflicts of interest

Personal funding was used for the project.

Open Access Article published under the Creative Commons Attribution CC-BY (CC) (P) 
vitro $^{5,6}$. In fact, IVIG has been successfully used as a steroid sparing agent in the treatment of an 8 year old boy with Kimura disease ${ }^{7}$. Renal involvement can occur in over $50 \%$ of patients with Kimura disease and usually takes the form of nephrotic syndrome ${ }^{8,9}$.

\section{References}

1. Saini A, Singh V, Chandra J, Dutta AK. Kimura's disease: An unusual glandular involvement with blood and tissue eosinophilia. Indian Journal of Pediatrics 2009; 76:647-8.

https://doi.org/10.1007/s12098-009-0160-8

PMid: 19618146

2. Jani A, Coulson M. Kimura's disease: A typical case of a rare disorder. Western Journal of Medicine 1997; 166:142-4. PMid: 9109334 PMCid: PMC1304036

3. Chow LT, Yuen RW, Tsui WM, Ma TK, Chow WB, Chan SK. Cytologic features of Kimura's disease in fine needle aspirates: A study of eight cases. American Journal of Clinical Pathology 1994; 102:316-21. https://doi.org/10.1093/ajcp/102.3.316 PMid: 8085555

4. Larroche C, Bletry O. Kimuras disease. Orphanet encyclopedia. February 2005. Available from:

https://www.orpha.net/data/patho/GB/ukkimura.pdf

5. Zhuang Q, Mazer B. Inhibition of $\operatorname{IgE}$ production in vitro by intact and fragmented intravenous immunoglobulin. Journal of
Allergy and Clinical Immunology 2001; 108(2):229 -34.

https://doi.org/10.1067/mai.2001.116291

PMid: 11496239

6. Sigman K, Ghibu F, Sommerville W, et al. Intravenous immunoglobulin inhibits $\operatorname{IgE}$ production in human B lymphocytes. Journal of Allergy and Clinical Immunology 1998; 102(3):421- 7 .

https://doi.org/10.1016/S00916749(98)7013 $0-7$

7. Hernandez-Bautista V, YamazakiNakashimada MA, Vazquez-García R, Stamatelos-Albarrán D, Carrasco-Daza D, Rodríguez-Lozano AL. Treatment of Kimura disease with intravenous immunoglobulin. Pediatrics 2011; 128(6). Available from:

http://pediatrics.aappublications.org/content/128/ 6/e1633 https://doi.org/10.1542/peds.2010-1623

PMid: 22106083

8. Othman SK, Daud KM, Othman NH. Kimura's Disease: A rare cause of nephrotic syndrome with lymphadenopathy. Malaysian Journal of Medical Sciences 2011; 18(4): 8890.

PMid: 22589678 PMCid: PMC3328941

9. Rajpoot DK, Pahl M, Clark J. Nephrotic syndrome associated with Kimura disease. Paediatric Nephrology 2000; 14(6): 486-8. https://doi.org/10.1007/s004670050799 